\title{
CURRENT ENDOVASCULAR MANAGEMENT OF INFECTED DISTAL BRANCH INTRACRANIAL ANEURYSMS: A CASE REPORT AND INSIGHT INTO THE LITERATURE
}

\author{
Vladimir Kalousek ${ }^{1}$, Tomislav Sajko ${ }^{2,3}$, Bruno Splavskii,3,4,5, Krešimir Rotim, ${ }^{2,3,4}$, \\ Mia Jurilj ${ }^{2}$, Branimir Čulo ${ }^{1}$ and Ante Rotim ${ }^{6}$
}

${ }^{1}$ Department of Radiology, Sestre milosrdnice University Hospital Centre, Zagreb, Croatia; ${ }^{2}$ Department of Neurosurgery, Sestre milosrdnice University Hospital Centre, Zagreb, Croatia; ${ }^{3}$ University of Applied Health Sciences, Zagreb, Croatia;

${ }^{4}$ Josip Juraj Strossmayer University of Osijek, Faculty of Medicine, Osijek, Croatia;

${ }^{5}$ Josip Juraj Strossmayer University of Osijek, Faculty of Dental Medicine and Health, Osijek, Croatia;

${ }^{6}$ Department of Neurosurgery, Dubrava University Hospital, Zagreb, Croatia

\begin{abstract}
SUMMARY - Infected intracranial aneurysms are a rare type of inflammatory vascular lesions that occur due to infection of intracranial arterial wall. Brain aneurysms of distal arterial branches are equally rare and frequently multiple, including those situated at the peripheral middle cerebral artery segments. Although both types represent a small percentage of all intracranial aneurysms, they may bring about high mortality in case of rupture. The management of such aneurysms includes conservative treatment with broad-spectrum antibiotics, and microsurgical or endovascular treatment, which is gaining more prominence for both asymptomatic and ruptured aneurysms. Herein, we present a case of a 61-year-old male patient with a history of cardiac infective disease and multiple bilateral aneurysms of infected distal branch middle cerebral arteries, discussing the efficacy of available endovascular treatment modalities and reviewing the literature. In conclusion, selective endovascular coiling is a preferable method in the current management of distal branch infected ruptured intracranial aneurysms, which may bring a favorable outcome.
\end{abstract}

Key words: Infected intracranial multiple aneurysms; Distal cerebral arterial branches; Aneurysmal rupture; Treatment modalities; Endovascular coiling; Outcome

\section{Introduction}

Infected intracranial aneurysms are a distinctive type of rare brain inflammatory vascular lesions that occur due to infection of intracranial vessel arterial wall ${ }^{1-4}$. They were primarily labeled in 1869 by W. S. Church, who described such an aneurysm in a young boy ${ }^{1,5}$, and named 'mycotic aneurysms' by Sir William

Correspondence to: Krešimir Rotim, $M D, P h D$, Department of Neurosurgery, Sestre milosrdnice University Hospital Centre, Vinogradska c. 29, HR-10000 Zagreb, Croatia

E-mail: profrotim@gmail.com

Received September 11, 2020, accepted November 20, 2020
Osler in 1885 while discussing the consequences of malignant endocarditis ${ }^{6}$, which still remains their primary etiology in the great majority of cases $^{2-4}$. The pathophysiology involves hematogenous dissemination from septic emboli, which is common, or straight bacterial extravascular invasion of the intracranial arterial wall due to meningitis, cerebral abscess, or cavernous sinus thrombophlebitis, which is $\mathrm{rare}^{1-4}$. Although such aneurysms are almost always secondary to bacterial infection, rare fungal and viral causes have been encountered too ${ }^{7,8}$.

While such aneurysms account for a small percentage $(0.7 \%-6.5 \%)$ of all intracranial aneurysms ${ }^{9,10}$, they 

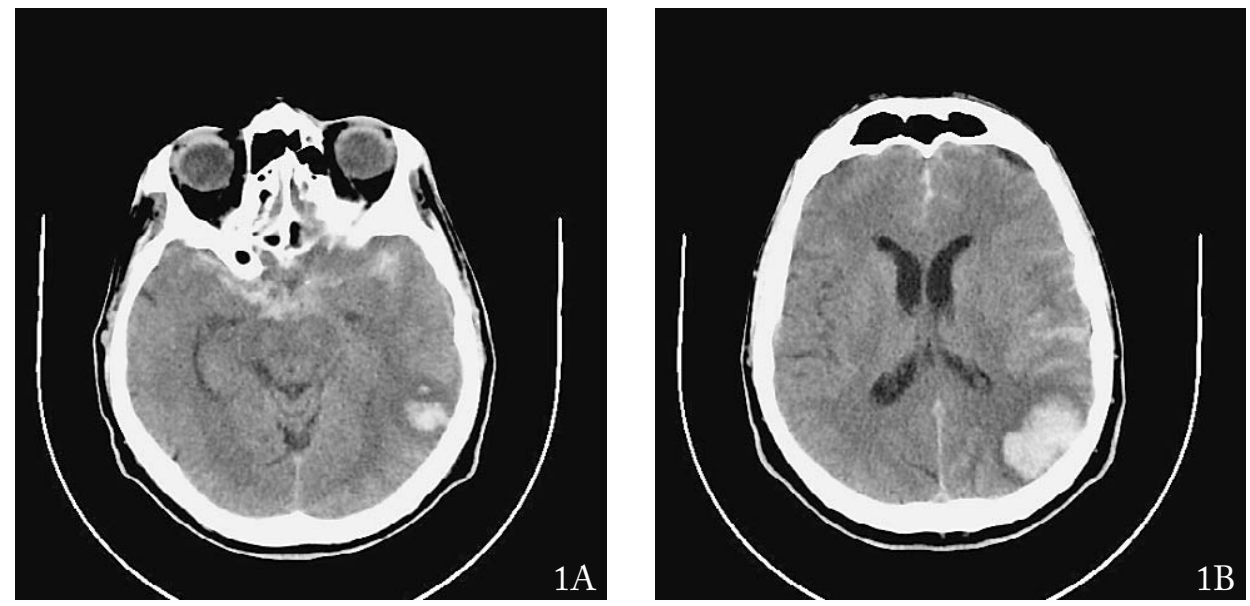

Fig. 1. Axial brain computed tomography showing subarachnoid hemorrhage in the area of suprasellar cisterns, and the left sylvian fissure, accompanied by minor subcortical intracerebral hematoma of the left parietal lobe, having no compressive effect $(A, B)$.

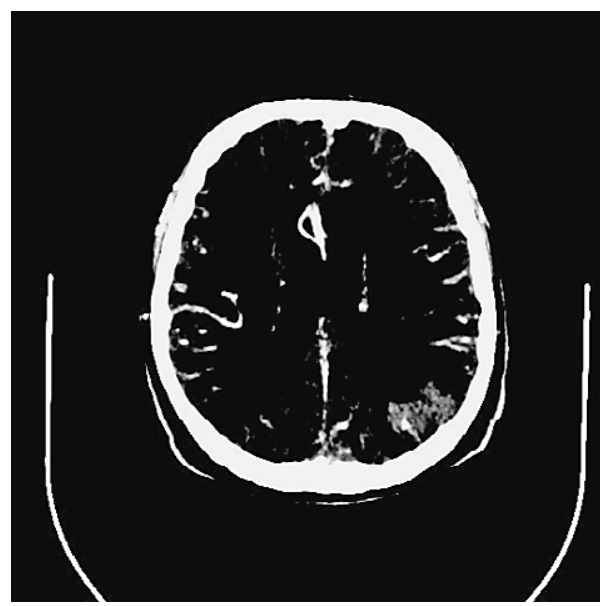

Fig. 2. Computed tomographic angiography disclosing a small ruptured saccular aneurysm of the M4 segment of the left middle cerebral artery situated within the intracerebral hematoma.

may be associated with high mortality in case of rupture $^{9,11}$, which is always accompanied by spontaneous and sudden subarachnoid hemorrhage $(\mathrm{SAH})$, and occasionally by intracerebral hemorrhage. Therefore, rupture prevention by timely diagnostics and early treatment is a prerequisite for evading unfavorable outcome when infected aneurysms are concerned.

Intracranial aneurysms of distal arterial branches are equally rare and often multiple, including those situated at the peripheral middle cerebral artery (MCA) segments, which constitute $4 \%-5 \%$ of all MCA aneurysms ${ }^{12,13}$.
One is always cautioned to suspect the infected aneurysm formation when there is a clue of a systemic infection found in natural history of the disease, particularly when bacterial endocarditis is observed. Hence, early diagnosis demands a high rank of suspicion and awareness by a clinician and neuroradiologist, bearing in mind that roughly one quarter of affected patients may develop multiple intracranial infected aneurysms $s^{1,2}$, which are predominantly situated at more peripheral/terminal vessel branches s $^{1,2,14}$.

The most effective diagnostic imaging for intracranial infected aneurysms includes brain computed tomography (CT), magnetic resonance imaging (MRI) and/or digital subtraction angiography (DSA) $)^{1,2,14,15}$, which is particularly consistent for discovering small aneurysms (of less than $3 \mathrm{~mm}$ in diameter) at distal/ terminal arterial branches ${ }^{16}$.

Management possibilities for such aneurysms include conservative treatment with broad-spectrum antibiotics, and microsurgical or endovascular treatment for both unruptured (asymptomatic) and ruptured aneurysms $s^{15}$. In recent literature, endovascular treatment consisting of different modalities is gaining more prominence ${ }^{17}$, becoming the most effective contemporary method to access aneurysms on distal branches of cerebral vessels ${ }^{18}$.

Herein, we present a case of a patient with multiple infectious intracranial aneurysms of distal branches, discussing the efficacy of available endovascular treatment modalities, and reviewing the literature. 

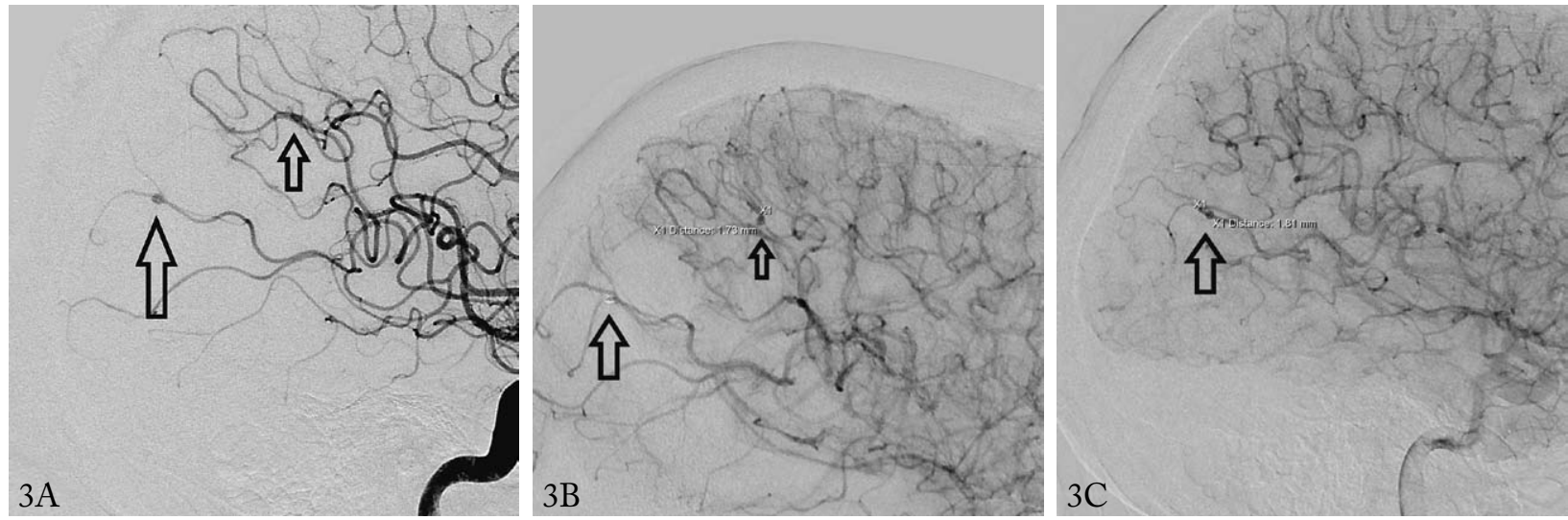

Fig. 3. Cerebral digital subtraction angiography lateral view visualizing the aneurysm and revealing an additional ipsilateral small unruptured middle cerebral artery aneurysm situated at different M4 segment $(A, B)$ (arrows), as well as contralateral small unruptured aneurysm situated at the opposite $M 4$ segment (C) (arrow).
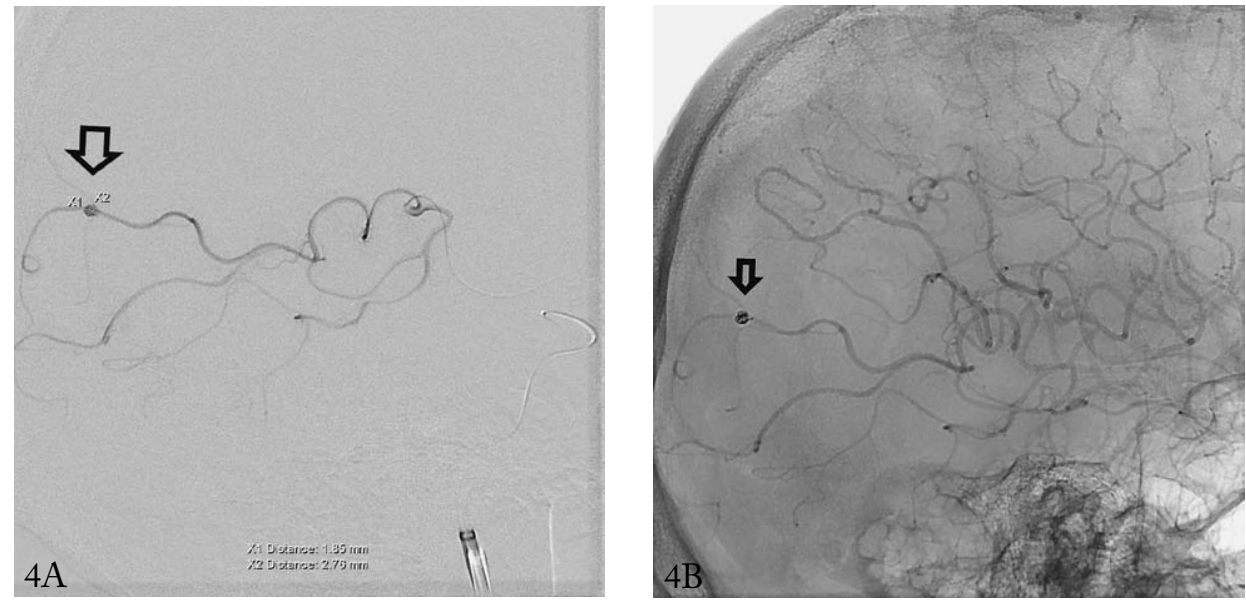

Fig. 4. Supra-selective view of the ruptured aneurysm occlusion by two detachable coils (A) (arrow), and cerebral digital subtraction angiography anterior-posterior view showing complete aneurysmal sac coil occlusion (B) (arrow).

\section{Case Report}

A 61-year-old male patient was treated at the Department of Cardiology due to dyspnea and highgrade mitral regurgitation with tendinous chord rupture. Prior to this event, infectious or autoimmune endocarditis was suspected. Besides cardiac disease, his past medical history was burdened with broad comorbidity including anemia, polyarthritis, arterial hypertension, chronic gastritis, benign prostatic hyperplasia, and chronic renal failure.

He presented to the Neurology Intensive Care Unit (ICU) with sudden onset of occipital headache.
He exposed no clinical features suggestive of an active systemic infection.

Urgent brain CT showed SAH in the area of suprasellar cisterns, and the left sylvian fissure, accompanied by minor subcortical intracerebral hematoma (ICH) of the left parietal lobe having no compressive effect (Fig. 1 A, B).

Computed tomographic angiography (CTA) disclosed a small ruptured saccular aneurysm of the M4 segment of the left MCA situated within the $\mathrm{ICH}$ as a cause of intracranial hemorrhage (Fig. 2). The aneurysm measuring $1.85 \times 2.76 \mathrm{~mm}$ in diameter, was confirmed and well visualized by cerebral DSA, which 


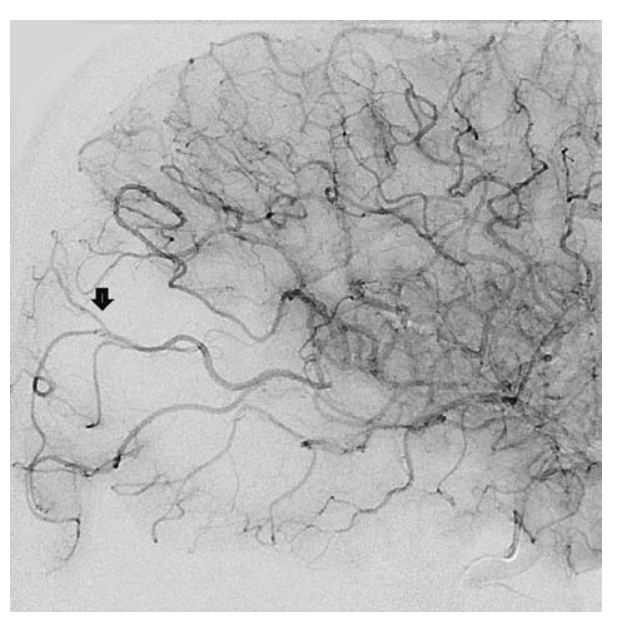

Fig. 5. Control digital subtraction angiography of the cerebral vessels, performed immediately after the procedure showing no residual aneurysmal filling (arrow).

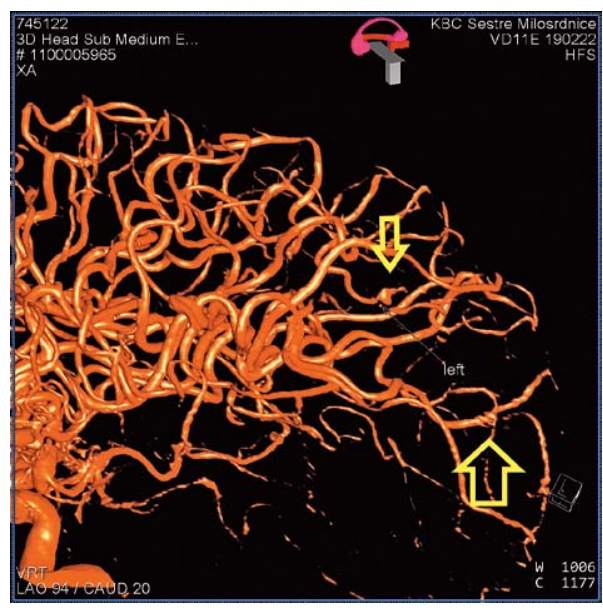

Fig. 6. Control 3-dimensional computed tomography angiography of the cerebral vessels showing complete occlusion of the aneurysmal sac (broad arrow), and revealing an additional ipsilateral unruptured small aneurysm at different M4 branch of the left middle cerebral artery (narrow arrow).

also revealed an additional small $(1.73 \mathrm{~mm}$ in diameter) ipsilateral unruptured MCA aneurysm at different M4 segment (Fig. 3 A, B) and contralateral small unruptured aneurysm measuring $1.81 \mathrm{~mm}$ situated at the opposite M4 segment (Fig. 3 C). A supra-selective ruptured aneurysm occlusion with two detachable coils was performed during the same procedure (Fig. 4 A, B), while the unruptured aneurysms were left intact. No residual filling of the ruptured aneurysm sac was visible on repeat DSA, which was performed immedi-

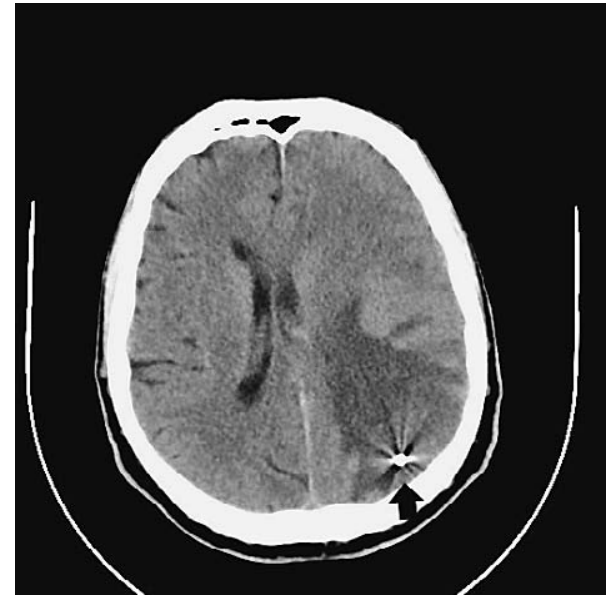

Fig. 7. Post-procedural plain axial computed tomography of the brain performed on follow-up day 12 depicting complete resolution of intracranial hemorrhage with metal artifact from aneurysmal coiling visible (arrow).

ately after the procedure (Fig. 5). Three-dimensional CT angiography (3D CTA) showed complete occlusion of the aneurysmal sac, and an additional ipsilateral unruptured small aneurysm at different M4 branch of the left MCA (Fig. 6). Post-procedural plain axial CT of the brain performed on follow-up day 12 depicted complete resolution of intracranial hemorrhage with metal artifact from aneurysmal coiling visible (Fig. 7).

Immediate post-procedural course was uneventful except for transitory sensory dysphasia and nominal aphasia, which resolved within 12 hours. No other neurological deficit or evidence for systemic bacterial infection was found.

On discharge, the patient was well recovered and transferred to Cardiac Surgery to be operated on (open heart surgery) due to mitral regurgitation. Broad-spectrum systemic antibiotic therapy was prescribed.

Magnetic resonance angiography (MRA) of the cerebral vessels was advised at 6-month follow-up after completion of cardiac surgical treatment.

\section{Discussion}

Infected intracranial aneurysms are uncommon ${ }^{9,10}$. They are frequently multiple and usually fusiform, as well as associated with rupture and other complications ${ }^{19}$. Non-treatment or delayed management of such aneurysms is often related to high morbidity and 
mortality due to possible fulminant sepsis ${ }^{19}$ and/or intracranial hemorrhage. However, it is not always easy to diagnose them prior to rupture, since they usually remain asymptomatic. This was the case in our patient, who presented with sudden onset of headache as the initial clinical sign of aneurysmal rupture, in whom multiple bilateral unruptured aneurysms were also found. Afterwards, it was revealed that he had previously suffered from a cardiac infectious disease and high-grade mitral regurgitation. Therefore, proper and timely evaluation of causal infectious disease is essential to establish the diagnosis ${ }^{20}$.

Intracranial aneurysms of distal branches of the cerebral arteries, including those of peripheral MCA segment, are rare, often multiple, and rather difficult to localize and treat ${ }^{21,22}$. However, advances in endovascular techniques have made distal aneurysms better manageable recently ${ }^{10,12}$. We managed our patient who developed an infected ruptured aneurysm of distal branch (M4) of the left MCA, in whom two additional unruptured aneurysms of bilateral distal MCA segments were also revealed, utilizing supra-selective endovascular coiling of the ruptured aneurysm.

The most common cause for the formation of distal arterial branch intracranial aneurysms is infection with septic (mycotic) emboli ${ }^{18,23} 24$, which was the origin of aneurysm development in our patient too. Besides, arterial vessel wall dissection was also described as a possible cause of distal aneurysmal formation ${ }^{23}$, while multiple aneurysms may also arise due to various reasons including radiation therapy of malignant diseases ${ }^{25}$.

Since distal aneurysms may generate problems for microsurgical management, it is better to consider endovascular techniques as the preferable treatment method $^{12}$. It may be a first-rate treatment modality in selected patients having high occlusion percentage and low complication rates when ruptured aneurysms are concerned ${ }^{26}$. Accordingly, we opted for selective endovascular coil embolization of the aneurysmal sac as optimal treatment modality in our patient. However, one has to be extremely cautious when coiling distal branch infected aneurysms due to their fragile wall, trying to preserve the small-caliber parent artery patency and diminish the risk of re-rupture as well ${ }^{18}$. Hence, in cases where the parent artery could not be spared, parent vessel occlusion with liquid embolic agent together with aneurysmal sac coiling has to be performed $^{12,17,24,26,27}$. Additionally, distal branch aneurysms that cannot be coiled can be treated with intra-aneu- rysmal injection of glue, which is also an efficient alternative to endovascular treatment ${ }^{21}$. Consequently, defining the best endovascular, microsurgical, or medical treatment still remains controversial ${ }^{28}$, allowing nonoperative treatment in the majority of patients regardless of aneurysmal rupture status ${ }^{29}$.

Bearing in mind the above mentioned options, as well as their potential advantages and/or pitfalls, we managed our patient with endovascular selective coiling, which resulted in good recovery and favorable outcome. Therefore, we believe that selective endovascular coiling is a preferable method for infected and distal branch intracranial aneurysms, while glue or liquid occlusion are treatment choices when the parent vessel has to be scarified.

However, personalized, multimodality, and interdisciplinary approach involving neurosurgeons, neurointerventionists, infectious disease experts, as well as cardiac surgeons is required in treatment decisionmaking to obtain optimal results ${ }^{28,30}$. Generally, it is advised to perform cranial procedures prior to cardiac surgical management, if necessary ${ }^{31}$.

In conclusion, selective endovascular coiling and preservation of the parent peripheral artery are preferable and secure methods used in contemporary management of distal branch infected intracranial aneurysms bringing a favorable outcome.

At the end, we would like to stress that this is a case report only, and therefore no definitive assumptions can be made regarding the best treatment option. Hence, further reading is necessary to support our conclusion.

\section{References}

1. Peters PJ, Harrison T, Lennox JL. A dangerous dilemma: management of infectious intracranial aneurysms complicating endocarditis. Lancet Infect Dis. 2006;6(11):742-8. doi: 10.1016/ S1473-3099(06)70631-4.

2. Ducruet AF, Hickman ZL, Zacharia BE, Narula R, Grobelny BT, Gorski J, et al. Intracranial infectious aneurysms: a comprehensive review. Neurosurg Rev. 2010;33(1):37-46. doi: 10.1007/ s10143-009-0233-1.

3. Zanaty M, Chalouhi N, Starke RM, Tjoumakaris S, Gonzalez LF, Hasan D, et al. Endovascular treatment of cerebral mycotic aneurysm: a review of the literature and single center experience. Bio Med Res Int. 2013;2013:151643. doi: 10.1155/ 2013/151643.

4. Kuo I, Long T, Nguyen N, Chaudry B, Karp M, Sanossian N. Ruptured intracranial mycotic aneurysm in infective endocar- 
ditis: a natural history. Case Rep Med. 2010;2010:168408. doi:10.1155/2010/168408.

5. Church WS. Aneurysm of the right cerebral artery in a boy of thirteen. Transactions of the Pathological Society of London. 1869;20:109.

6. Osler W. The Gulstonian Lectures, on malignant endocarditis. BMJ. 1885;1(1262):467-70.

7. Singh D, Pinjala RK, Purohit AK, Reddy LR, Bhattacharjee S. Giant mycotic aneurysm of the vertebral artery: a case report. J Vasc Surg. 2005;42(2):348-51. doi: 10.1016/j.jvs.2005.04.025.

8. Molinari GF, Smith L, Goldstein MN, Satran R. Pathogenesis of cerebral mycotic aneurysms. Neurology. 1973;23(4):325-32.

9. Kannoth S, Thomas SV. Intracranial microbial aneurysm (infectious aneurysm): current options for diagnosis and management. Neurocrit Care. 2009;11(1):120-9. doi: 10.1007/s12028009-9208-x.

10. Petr O, Brinjikji W, Burrows AM, Cloft H, Kallmes DF, Lanzino G. Safety and efficacy of endovascular treatment for intracranial infectious aneurysms: a systematic review and metaanalysis. J Neuroradiol. 2016;43(5):309-16. doi: 10.1016/j. neurad.2016.03.008.

11. Watanabe A, Hirano K, Ishii R. Cerebral mycotic aneurysm treated with endovascular occlusion - case report. Neurol Med Chir. 1998;38(10):657-60. doi: 10.2176/nmc.38.657.

12. Baltacioğlu F, Cekirge S, Saatci I, Öztürk H, Arat A, Pamir N, et al. Distal middle cerebral artery aneurysms. Endovascular treatment results with literature review. Interv Neuroradiol. 2002;8(4):399-407. doi: 10.1177/159101990200800409.

13. Rinne J, Hernesniemi J, Niskanen M, Vapalahti M. Analysis of 561 patients with 690 middle cerebral artery aneurysms: anatomic and clinical features as correlated to management outcome. Neurosurgery. 1996;38:2-11. doi: 10.1097/00006123199601000-00002.

14. Messori A, Lanza C, De Nicola M, Menichelli F, Capriotti T, Morabito L, et al. Mycotic aneurysms as lethal complication of brain pseudallescheriasis in a near-drowned child: a CT demonstration. AJNR Am J Neuroradiol. 2002;23(10):1697.

15. Hess A, Klein I, Iung B, Lavallée P, Ilic-Habensus E, Dornic $\mathrm{Q}_{2}$ et al. Brain MRI findings in neurologically asymptomatic patients with infective endocarditis. AJNR Am J Neuroradiol. 2013;34(8):1579-84. doi: 10.3174/ajnr.A3582.

16. Allen LM, Fowler AM, Walker C, Derdeyn CP, Nguyen BV, Hasso AN, et al. Retrospective review of cerebral mycotic aneurysms in 26 patients: focus on treatment in strongly immunocompromised patients with a brief literature review. AJNR Am J Neuroradiol. 2013;34(4):823. doi: 10.3174/ajnr.A3302.

17. Chapot R, Houdart E, Saint-Maurice JP, Aymard A, Mounayer C, Lot G, et al. Endovascular treatment of cerebral mycotic aneurysms. Radiology. 2002;222(2):389-96. doi: 10.1148/ radiol.2222010432.

18. Chun JY, Smith W, Van Halbach V, Higashida RT, Wilson CB, Lawton MT. Current multimodality management of infectious intracranial aneurysms. Neurosurgery. 2001;48(6):1203-14. doi: 10.1097/00006123-200106000-00001.
19. Lee WK, Mossop PJ, Little AF, Fitt GJ, Vrazas JI, Hoang JK, et al. Infected (mycotic) aneurysms: spectrum of imaging appearances and management. Radiographics. 2008;28:1853-68. doi: $10.1148 / \mathrm{rg} .287085054$.

20. Bae TW, Chung J, Ahn JS, Ko JH. Unusual presentation of infectious intracranial aneurysm with sequential hemorrhagic and ischemic components. J Cerebrovasc Endovasc Neurosurg. 2020;22(2):90-6. doi: 10.7461/jcen.2020.22.2.90.

21. Cognard C, Weill A, Tovi M, Castaings L, Rey A, Moret J. Treatment of distal aneurysms of the cerebellar arteries by intraaneurysmal injection of glue. Am J Neuroradiol. 1999;20: 780-4.

22. Steinberg GK, Guppy KH, Adler JR, Silverberg GD. Stereotactic, angiography-guided clipping of a distal, mycotic intracranial aneurysm using the Cosman-Roberts-Wells system: technical note. Neurosurgery. 1992;30:408-11. doi: 10.1227/ 00006123-199203000-00016.

23. Piepgras DG, McGrail KM, Tazelaar HD. Intracranial dissection of the distal middle cerebral artery as an uncommon cause of distal cerebral artery aneurysm. Case report. J Neurosurg. 1994;80:909-13. doi: 10.3171/jns.1994.80.5.0909.

24. Khayata MH, Aymard A, Casasco A, Herbreteau D, Woimant F, Merland JJ. Selective endovascular techniques in the treatment of cerebral mycotic aneurysms. J Neurosurg. 1993;78: 661-5. doi: 10.3171/jns.1.

25. Rotim K, Splavski B. Trkanjec Z, Kalousek V, Rotim A, Sajko T. Risk for multiple intracranial aneurysm formation in $\mathrm{pa}^{-}$ tients with malignant disease undergoing radiation therapy. A case report and literature review. Acta Clin Croat. 2020;59 (2):359-64. doi: 10.20471/acc.2020.59.02.21

26. Gross BA, Puri AS. Endovascular treatment of infectious intracranial aneurysms. Neurosurg Rev. 2013;36(1):11-9. doi: 10.1007/s10143-012-0414-1.

27. Chalouhi N, Tjoumakaris S, Gonzalez LF, Hasan D, Alkhalili $\mathrm{K}$, Dumont AS, et al. Endovascular treatment of distal intracranial aneurysms with Onyx 18/34. Clin Neurol Neurosurg. 2013;115(12):2528-32. doi: 10.1016/j.clineuro.2013.10.018.

28. Matsubara N, Miyachi S, Izumi T, Yamanouchi T, Asai T, Ota $\mathrm{K}$, et al. Results and current trends of multimodality treatment for infectious intracranial aneurysms. Neurol Med Chir (Tokyo). 2015;55(2):155-62. doi: 10.2176/nmc.oa.2014-0197.

29. Singla A, Fargen K, Blackburn S, Neal D, Martin TD, Hess PJ, et al. National treatment practices in the management of infectious intracranial aneurysms and infective endocarditis. J Neurointerv Surg. 2016;8(7):741-6. doi: 10.1136/neurintsurg-2015-011834.

30. Hamisch CA, Mpotsaris A, Timmer M, Reiner M, Stavrinou $\mathrm{P}$, Brinker $\mathrm{G}$, et al. Interdisciplinary treatment of intracranial infectious aneurysms. Cerebrovasc Dis. 2016;42(5-6):493-505. doi: 10.1159/000448406

31. Fujita W, Daitoku K, Taniguchi S, Fukuda I. Infective endocarditis with cerebral mycotic aneurysm: treatment dilemma. Gen Thorac Cardiovasc Surg. 2010;58:622-5. doi: 10.1007/s11748009-0581-3. 


\title{
Sažetak \\ SUVREMENO ENDOVASKULARNO LIJEČENJE INFICIRAJUĆIH INTRAKRANIJSKIH ANEURIZMA DISTALNIH OGRANAKA: PRIKAZ SLUČAJA I UVID U LITERATURU
}

\author{
V. Kalousek, T. Sajko, B. Splavski, K. Rotim, M. Jurilj, B. Čulo i A. Rotim
}

Inficirajuće intrakranijske aneurizme rijedak su tip inflamatorne vaskularne bolesti koji nastaje uslijed upalnih promjena arterijske stijenke moždanih krvnih žila. Aneurizmatske tvorbe distalnih arterijskih ogranaka podjednako su rijetke i učestalo višestruke, uključujući i one nastale na završnim odsječcima srednje moždane arterije. Iako oba tipa predstavljaju mali postotak u učestalosti intrakranijskih aneurizma, one mogu biti uzrokom povećane smrtnosti u slučaju rupture. Liječenje ovakvih aneurizma sastoji se od primjene antibiotika širokog spektra djelovanja, kao i od mikrokirurškog ili raznih oblika endovaskularnog liječenja, koje je sve zastupljenije u slučaju asimptomatskih i rupturiranih aneurizma. U ovom radu dajemo prikaz bolesnika u dobi od 61 godine s opsežnim komorbiditetom uključujući i upalnu bolest srca, koji je liječen zbog višestrukih obostranih inficirajućih aneurizma distalnih ogranaka srednje moždane arterije. Također raspravljamo o učinkovitosti postojećih endovaskularnih metoda liječenja te donosimo uvid u relevantnu literaturu. Zaključujemo kako je selektivna endovaskularna embolizacija zavojnicama preporučljiva metoda suvremenog liječenja rupturiranih inficirajućih aneurizma distalnih intrakranijskih arterijskih ogranaka, koja može rezultirati povoljnim ishodom.

Ključne riječi: Inficirajuća intrakranijska aneurizma; Distalni cerebralni arterijski ogranci; Ruptura aneurizme; Modaliteti liječenja; Endovaskularna embolizacija; Ishod 